\title{
Examination of Obesity Awareness Levels of Physical Education Teacher and Coaching Education
}

\author{
Ayça Genç ${ }^{1}$, Aygül Çağlayan Tunç² \\ ${ }^{1}$ Bartin University, Faculty of Sport Science, Turkey \\ ${ }^{2}$ Sport Science Faculty, Sport Psychology, Turkey \\ Correspondence: Ayça Genç, Bartin University, Faculty of Sport Science, Turkey.
}

Received: November 29, 2019

Accepted: December 18, 2019 Online Published: December 23, 2019

doi:10.11114/jets.v8i2.4638

URL: https://doi.org/10.11114/jets.v8i2.4638

\begin{abstract}
In this study, it was aimed to examine obesity awareness levels of physical education teacher and coaching education students.251 (103 women, age:20,36 $\pm 2,31$ years, BMI:20,02 $\pm 2,23 \mathrm{~kg}$ ) who studied in the Department of Coaching and Physical Education of Bartin University Faculty of Sport Sciences in 2019-2020 academic year were included in this study. 147 male, age:20.15 \pm 2.32 years, BMI:21.42 $\pm 2.67 \mathrm{~kg} / \mathrm{m} 2)$ students participated voluntarily. Obesity Awareness Scale was developed by Allen (2011) and adapted to Turkish by Kafkas and Özen (2014) and personal information form including age, gender and department variable were applied to the participants. The data obtained in the study were analyzed with SPSS 20.0 statistical package program and the level of significance was taken as $(\mathrm{p}<0.05)$. The overall internal consistency of the scale was found to be 0.87 . In the study, $t$-test was used for pairwise comparisons of parametric tests. In our study, no significant difference was found between gender variable and obesity awareness ( $>$ >.05). There was no significant difference between obesity awareness and department variable ( $>$.05). When the obesity awareness scores were examined, the average score of the students of the coaching department was average 62.23 meanwhile the teaching department students average score 62,91. It was found that both physical education teachers and coaching department students had high obesity awareness, but there was no significant difference between the groups in terms of department and gender variables and obesity awareness.
\end{abstract}

Keywords: obesity awareness level, physical education teacher, coaching education

\section{Introduction}

It is seen that the faculties that provide physical education and coaching education are also guiding in issues related to public health besides education and training activities. Exercise is an important factor that supports cognitive, affective and psychomotor development. In addition, exercise is a protective tool against diseases such as obesity, cardiovascular disorders, diabetes and depression.

People with a BMI of 30 or over are considered to be obese, causing excessive and abnormal fat build-up and disrupting body health. (https://hsgm.saglik.gov.tr/en/obezite/obezite-nedir.html) In obesity measurement, body mass index (BMI) is calculated by dividing the weight $(\mathrm{kg})$ of the individual by the square of his height $(\mathrm{m})$. In adults, BMI is considered to be overweight if it is between $25-29.9 \mathrm{~kg} / \mathrm{m} 2$ and obese if it is $30 \mathrm{~kg} / \mathrm{m} 2$. Individuals with a BMI of 35 and over are classified as morbidly obese with high vital risks (Çiçekli, 2019).

In the formation of obesity; genetics, endocrine disorders, eating habits, unhealthy eating, lack of physical activity, gender, age, smoking, alcohol, drug use, stress, environmental, cultural and psychological factors play a key role (Kahraman, 2018; Park et al., 2018). Obesity is a disease that causes physiological, organic and systemic problems as well as psychological problems. The fact that one of the reasons effective in the formation of obesity appears in individuals triggers the formation of other factors. For example; The hormonal structure of someone with intense stress may be impaired (Zorba, 2014). Today, obesity, psycho-somatic deterioration or, as a disease with a different definition of psychological factors contributed to the literature (Resch et al. 1998). The human body, the soul and the body are whole, intertwined living creatures. It is affected by mental changes in bodily functions. In humans, there is a mutual interaction between psychological state and increased appetite. Emotional and mental changes such as depression, tension, anxiety, sadness and joy affect the eating habits and eating behaviors of people (Eren and Erdi 2003). Obesity is a result of various factors. It is known that many psychological factors such as eating speed, stress, depression, loss of a 
relative, loneliness, unhappiness and frustration cause weight gain. In particular, individuals with mental depression tend to snack in order to get rid of tension. Generally, depressed individuals can also observe weight gain (Fox and Byerly 2001). The main causes of obesity are nutritional disorders and unconsciousness in calorie intake. Unfortunately, people are unaware of the amount of calories they need to consume daily and the calories of foods, increasing awareness of calories can play an active role in preventing obesity. The international food information council reported that only one in every seven Americans correctly estimated the amount of calories needed daily. Apart from eating habits and mood, it has a significant effect on genetic factors in obesity. Hereditary inheritance influences the way and degree of nutrition in various ways (Guyton and Hall 2001). We can define them as follows. In the nutrition center, abnormal conditions seen in the regulation of energy stores, conditions that cause appetite or people to eat, abnormal genetic and psychological factors, and genetic disorders such as abnormal fat-carbohydrate storage can be listed. Because of obesity, some psychological and physiological diseases occur in humans. Some researchers interested in the obese gene believe that a gene that is thought to cause a tendency to increase weight causes obesity (Bouchard 2001). Obesity, known as the disease of our age, causes many diseases in the world and in our country and its incidence is gradually increasing. Obesity, which directly affects the quality of life and life span of people, causes psychological and social problems and triggers the emergence of some chronic diseases (Cabıoğlu et al., 2003). Obesity; Diabetes, hypertension, metabolic syndrome, cardiovascular disorders, respiratory and digestive system disorders are highly associated with cancer types and are ranked fifth among the most important mortality factors (Kalan and Yeşil, 2010; Pereira-Santos et al., 2015).

The World Health Organization has reported that the prevalence of obesity has increased threefold in the last 20 years in the European Region (WHO, 2007). According to OECD data, the USA with the highest obesity rate is $38.2 \%$ in the world while the lowest obesity rate is seen in Japan with $3.7 \%$. the obesity rate in Turkey is around $22.3 \%$ (https://www.tuseb.gov.tr/akademik/obezite-hakkinda-oecd-raporu). According to the $2008 \mathrm{WHO}$ statistics, obesity prevalence was higher in men 20 years of age in the world, while $20.4 \%$, this rate in Turkey $22.8 \%$, the prevalence of obesity in the world, women $35.6 \%$ in Turkey, while $23.1 \%$ is around (Yanıkkerem, 2017). The World Health Organization (WHO) conducted an epidemiological assessment of 10-20 years in a study conducted in 6 regions: Africa, America, South Asia, Eastern Mediterranean, Europe and Western Pacific. According to the results of the study, the prevalence of obesity increased by $10-40 \%$, on average $15-20 \%$ of males and $22 \%$ of females are currently obese (Günay et al., 2006).

Studies have shown that obesity has a high health, social and economic impact on individuals and society (Lakerveld et al., 2014). Obesity ranks third in terms of the burden on the national economy today in terms of material loss after smoking, terrorism and war crimes (Dobbs et al.,2014). Obesity treatment is a very costly disorder, with the US spending \$ 147 billion annually on obesity, the most obesity seen, and each year 3.4 million people die due to obesity-related problems worldwide (Perlmutter and Loberg, 2017).

Obesity is one of the physiological, psychological, social and global problems that can be brought under the influence of heredity and can develop due to environmental factors and neurological reasons. In today's world where human health and quality of life are important, people have become aware of the importance of healthy eating and physical activity. From this perspective, physical activity, nutrition and weight control should be the way of living people. Today body and mental health are known to be a whole. Although awareness about obesity has increased recently in our society, the rate of obesity continues to increase. The perception of obesity is an important determinant for behavior or action in the field of health promotion. The perception of obesity disease and risk factors by people at different levels of society (policy, health and social work, public health and prevention, teachers, schools, etc.) will contribute to the prevention and management strategy of obesity (Visscher et al., 2015). Although many studies have been observed in the literature on obesity prevalence, risk factors and related diseases, exercise and obesity relationship, studies on obesity awareness are limited.

\section{Method}

\subsection{Research Model}

This study is a randomized sampling method used to test the obesity awareness levels of physical education teachers and coaching education students in terms of department and gender variables (Karasar, 2012).

\subsection{Population and Sample of the Research}

In this study, it was aimed to examine obesity awareness levels of physical education teacher and coaching education students. The sample of the research group consisted of 251 students (103 females, 147 males) studying in the coaching and physical education department of Bartın University Faculty of Sport Sciences in the 2019-2020 academic year. The volunteering principle was used in the application of the scales to the sample group. 


\subsection{Data Collection Tools}

In order to determine some demographic characteristics of the participants, Obesity Awareness Scale was used to determine the personal information form of the participants including age, gender, height, department variables, and obesity knowledge levels.

\subsubsection{Obesity Awareness Scale}

Obesity Awareness Scale developed by Allen (2011) and adapted to Turkish by Kafkas and Özen (2014) and personal information form including age, gender and department variables were applied to the participants. The scale consists of 20 items and three sub-dimensions (a-obesity awareness and risk factors, b-nutrition sub-dimension, c-physical activity sub-dimension). The scale has a 4-point likert structure from negative to positive. When the 16th question is scored in the scale, it is read in reverse and calculated as $<20$ average awareness over 20 points, low awareness between 20-39 points, low awareness between $40-59$ points and high awareness between $60-80$ points.

\subsection{Analyzing Data}

The data obtained in the study were analyzed with SPSS 20.0 statistical package program and the level of significance was taken as $(\mathrm{p}<0.05)$. The internal consistency of the scale was found to be 0.87 . Cronbach's alpha value was found to be 0.87 . In the study, t-test was used for pairwise comparisons of parametric tests.

\section{Results}

The findings of the study which investigated the obesity awareness of physical education teacher and coaching education students are presented below.

Table 1. Age and BMI Table of Female and Male Group

\begin{tabular}{lrc}
\hline Gender & Height & BMI \\
\hline Female Group & $20,36 \pm 2,31$ & $20,02 \pm 2,23$ \\
Male Group & $20,15 \pm 2,32$ & $21,42 \pm 2,67$ \\
\hline
\end{tabular}

The mean age of the women participating in the study was approx. The mean age was $20.36 \pm 2.31$ years and BMI was $20.02 \pm 2.23 \mathrm{~kg} / \mathrm{m} 2.20 .15 \pm 2.32$ years, BMI was found to be $21.42 \pm 2.67 \mathrm{~kg} / \mathrm{m} 2$.

Table 2. Examination of Obesity Awareness by Gender Variable

\begin{tabular}{lllllll}
\hline Gender & $\mathrm{N}$ & $\mathrm{X}$ & $\mathrm{S}$ & $\mathrm{sd}$ & $\mathrm{t}$ & $\mathrm{p}$ \\
\hline Female & 103 & 62,4 & 5,31 & & & \\
Male & 147 & 62,8 & 5,79 & & & \\
\hline $\mathrm{P}<0.05$ & & & & & &
\end{tabular}

When Table 2 was examined, no significant difference was found between gender variables and obesity awareness of the participants ( $\mathrm{p}>.05)$.

Table 3. Examination of Obesity Awareness by Part Variable

\begin{tabular}{lcccccc}
\hline & $\mathrm{N}$ & $\mathrm{X}$ & $\mathrm{S}$ & $\mathrm{sd}$ & $\mathrm{t}$ & $\mathrm{p}$ \\
\hline Coaching & 126 & 62,23 & 6,14 & & & \\
& & & & 97 &, 95 &, 09 \\
Physical Education Teacher & 124 & 62,91 & 4,96 & & & \\
\hline
\end{tabular}

$$
\mathrm{P}<0.05
$$

When Table 3 was examined, no significant difference was found between the participants' variables and obesity awareness ( $p>.05)$. However, when the obesity awareness scores were examined, the average score of the students of the coaching department was average. While 62.23 mean score of students in the department of physical education teachers. 62,91 . When the mean scores of both groups were taken into consideration, it was found that the groups had high obesity awareness.

\section{Discussion}

In this study, obesity awareness levels of physical education teacher and coaching education students were examined.

When the literature is examined, various studies have been observed to measure obesity awareness and to prevent the 
increase in the incidence of obesity in the society. In a study examining the news published by some of the top five newspapers about obesity in selected months, 49 of the reports were related to obesity, 44 of the current or magazines had content on obesity prevention, 39 had treatment, 35 had health risks and 13 of these patients were found to cover the complication issue (Demircioğlu et al., 2013).

Li et al., (2010), wanted to draw attention to childhood obesity in their study, and students with low socioeconomic status increased BMI observed that exercise is a factor affecting obesity. In a study conducted in Korea on the frequency, awareness and management of obesity between 1998 and 2011, it was found that the prevalence of obesity increased year by year, and individuals with various disorders such as diabetes and obese individuals had less awareness than subjects with weak or normal weight (Kim et al., 2014). In a study conducted in 447 primary schools in Malaysia, it was found that $90 \%$ of school administrators have knowledge about obesity prevention policies, but 50-70\% of schools implement this policy. They stated that the main reason for this was inadequate education, lack of sufficient time to complete the applications and lack of equipment (Chan et al., 2018). In the study of obesity and dietary awareness among young people and children in Poland, 9\% of the population was overweight and 5\% were obese, and the main reasons for this were nutrient consumption, lack of physical activity, and excessive spending on TV and computer. respectively. They also reported that girls had a higher level of consciousness compared to boys, but that being conscious and aware was not sufficient to maintain optimal body mass (Stankiewicz et al., 2014). In Obafemi Awolowo University communities, the study carried out to measure the awareness of obesity among 236 female subjects aged 25-59 years $76.7 \%$ of women had low awareness about obesity awareness and health damage, and it was found that the level of education decreased and the awareness decreased (Ojofeitimi et al., 2007). One hundred people in the 19-50 age group and 40 adolescents in the 14-18 age group in Tanzania showed that $70 \%$ of the young group had lower obesity awareness than the older group (Nyaruhucha et al., 2003). It was found by this study which examined the obesity awareness among university students with 800 students from 16 departments, women had higher obesity awareness than men, sociology students had lower obesity awareness rate than education faculty, physical therapy and rehabilitation, sports science faculty students, and obesity awareness levels increased as university students increased their class levels (Sözen ve Bebek, 2018).

As a result, it was found that both physical education teachers and coaching department students had high obesity awareness, but there was no significant difference between the groups in terms of department and gender variables and obesity awareness.

\section{Suggestions}

Obesity has become a global problem due to the high cost of treatment and mortality. Obesity awareness is important for families and teachers. Regular exercise and healthy nutrition in all age groups are protective against obesity. In this context, the fact that physical education teachers and coaches are more conscious and aware of obesity is important in preventing obesity. There is a need for greater awareness of the impact of obesity on people's health through information, education and communication.

\section{References}

Allen, A. (2011). Effects of educational intervention on children's knowledge of obesity risk factors. (Ph.D. Thesis). Carroll College.

Bouchard, C. (2001). The genetics of human obesity: recent progress. Bull Mem Acad R Med Belg, 156, 455-462.

Cabıoğlu, M. T., Ergene, N., \& Bodur, S. (2003). Obezlerde ağırlık kaybı için uygulanan elektroakupunktur ve diyet tedavisinin serum lipid düzeylerine akut etkileri. Selçuk Üniversitesi Tip Fakültesi Dergisi 19(3), 145-150.

Chan, C., Moy, F. M., Lim, J. N. W., \& Dahlui, M. (2018). Awareness Facilitators and Barriers to Policy Implementation Related to Obesity Prevention for Primary School Children in Malaysia. American Journal of Health Promotion, 32(3), 806-811. https://doi.org/10.1177/0890117117695888

Çiçekli, İ. (2019). Maternal Obesity and Nutrition. Nutrition and Obesity (First Edition). İstanbul, Güven Plus. 107-112.

Demircioglu, S., Bulanık, E., Cennet, O., Boybay, Z., Benderlioglu, E., \& Aslan, D. (2013). Content Analyses of Obesity News at High Circulated National Newspapers On March, August, October 2011 and February 2012. TAF Preventive Medicine Bulletin, 12(3), 271-282. https://doi.org/10.5455/pmb.1-1342442709

Dobbs, R., Sawers, C., Thompson, F., et al. (2014). Overcoming obesity: An initial economic analysis. Mc Kinsey Global Institute, 13.

Eren, İ., \& Erdi, Ö. (2003). Obez hastalarda psikiyatrik bozuklukların sıklığı. Klinik Psikiyatri Dergisi, 6(3), 152-157.

Fox, E. A., \& Byerly, M. S. (2003). A mechanism underlying mature-onset obesity: evidence from the hyperphagic phenotype of brain-derived neurotrophic factor mutants. Am J Physiol Regul Integr Comp Physiol, 286, 994-1004. 
https://doi.org/10.1152/ajpregu.00727.2003

Fruh, S., \& Fulkerson, J. (2014). Calorie Awareness Related to Weight Control. J Contin Educ Nurs., 45(1), 10-11. https://doi.org/10.3928/00220124-20140103-13

Günay, M., Cicioğlu, İ., \& Kara, E. (2006). Metabolic and Heat Adaptation to Exercise. Ankara, Gazi Kitabevi, 240. https://hsgm.saglik.gov.tr/tr/obezite/obezite-nedir.html

Guyton, A. C., \& Hall, J. E. (2001). Textbook of Medical Physiology. İstanbul, Nobel Kitabevi, 2001, 797-800.

Kafkas, M. E., \& Ozen, G. (2014). Adaptation of Obesity Awareness Scale (OFÖ) to Turkish: A Validity and Reliability Study. İnönü University Journal of Physical Education and Sports Sciences, 1(2), 1-15.

Kahraman, Ç. (2018). Nutrition Habits and Obesity Risk in University Students: The Sample of Tekirdăg Namık Kemal University. (Master Thesis). Institute of Social Sciences, Namık Kemal University.

Kalan, I., \& Yeşil, Y. (2010). Chronic Diseases Associated with Obesity. Turkish Pharmacists Association Continuing Education Magazine, 23-24, 78-81.

Karasar, N. (2012). Scientific research method (23rd edition). Ankara, Nobel Publishing House.

Kim, C. S., Ko, S. H., Kwon, H. S., Kim, N. H., Kim, J. H., Lim, S., ... Cha, B. Y. (2014). Taskforce Team of Diabetes Fact Sheet of the Korean Diabetes Association. Prevalence, Awareness, and Management of Obesity in Korea: Data from the Korea National Health and Nutrition Examination Survey (1998-2011). Diabetes Metab J., 38(1), 35-43. https://doi.org/10.4093/dmj.2014.38.1.35

Li, J., \& Hooker, N. H. (2010). Childhood obesity and schools: evidence from the national survey of children's health. Journal of School Health, 80(2), 96-103. https://doi.org/10.1111/j.1746-1561.2009.00471.x

Nyaruhucha, C. N. M., Achen, J. H., Msuya, J. M., Shayo N. B., \& Kulwa, K. B. M. (2003). Prevalence and awareness of obesity among different age groups in educational institutions in Morogoro, Tanzania. African Medical Journal, 80(2), 68-72. https://doi.org/10.4314/eamj.v80i2.8648

Ojofeitimi, E. O., Adeyeye, A. O., Fodiora, A. O., et al. (2007). Awareness of Obesity and it's Health Hazard Among Women in the University Community. Pakistan Journal of Nutrition, 6(5), 502-505. https://doi.org/10.3923/pjn.2007.502.505

Park, J. E., Pichiah, P. B. T., \& Cha, Y. S. (2018). Vitamin D and Metabolic Diseases: Growing Roles of Vitamin D. J Obes Metab Syndr, 27(4), 223-232. https://doi.org/10.7570/jomes.2018.27.4.223

Pereira-Santos, M., Costa, P, R., Assis, A. M., Santos, C. A., \& Santos, D. B. (2015). Obesity and vitamin D deficiency: a systematic review and meta-analysis. Obes Rev., 16(4), 341-349. https://doi.org/10.1111/obr.12239

Perlmutter, D., \& Loberg, K. (2017). Brain and intestines. (1st Edition). Istanbul: Pegasus Publications. 15-125.

Resch, M., Haasz, P., \& Sido, Z. (1998). Obesity as psychosomatic disease. European Psychiatry, 13(Sup), 315. https://doi.org/10.1016/S0924-9338(99)80652-X

Sözen, H., \& Bebek, G. (2018). Determination of Obesity Awareness of University Students. International Congress on Political, Economic and Social Studies. Oral Presentation Congress.

Stankiewicz, M., Pieszko, M., Śliwińska, A., Małgorzewicz, S., Wierucki, Ł., Zdrojewski, T., ... Łysiak-Szydłowska, W. (2014). Obesity and Diet Awareness among Polish Children and Adolescents in Small Towns and Villages. Cent Eur J Public Health, 22(1), 12-16. https://doi.org/10.21101/cejph.a3813

Visscher, T. L., Heitmann, B. L., Rissanen, A., Lahti-Koski, M., \& Lissner, L. (2015). A break in the obesity epidemic? Explained by biases or misinterpretation of the data? Int J Obes., 39, 189-198. https://doi.org/10.1038/ijo.2014.98

World Health Organization. The challenge of obesity in the WHO European Region and the strategies for response: summary. Copenhagen. WHO Regional Office for Europe, 2007.

Yanıkkerem, E. (2017). Effects of obesity on women's health. Kocaeli University Journal of Health Sciences, 3(1), 37-43. https://doi.org/10.30934/kusbed.359281

Zorba, E. (2014). Lifetime Sports. Ankara, Atalay Matbaacillk. 116.

\section{Copyrights}

Copyright for this article is retained by the author(s), with first publication rights granted to the journal.

This is an open-access article distributed under the terms and conditions of the Creative Commons Attribution license which permits unrestricted use, distribution, and reproduction in any medium, provided the original work is properly cited. 